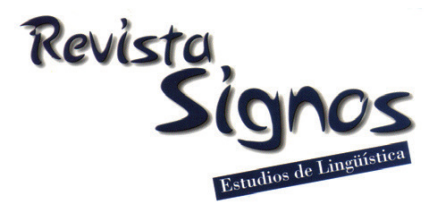

\title{
The semantic prosody of the words inmigración and inmigrante in the Spanish written media: A corpus-based study of two national newspapers
}

\author{
La prosodia semántica de las palabras 'inmigración'e \\ 'inmigrante' en la prensa escrita española: Estudio basado-en- \\ corpus de dos periódicos nacionales
}

\section{Gema Alcaraz-Mármol}

UNIVERSIDAD CATÓLICA DE MURCIA

ESPAÑA

galcaraz@ucam.edu
Jorge Soto Almela

UNIVERSIDAD CATÓLICA DE MURCIA ESPAÑA jsalmela@ucam.edu

Recibido: 09/IV/2014 / Aceptado: 12/VIII/2015

\begin{abstract}
Several studies, such as the one carried out by Checa and Arjona (2011), show the negative view of the Spanish media towards immigration from a social perspective, in which immigration is conceived as a threat and an invasion that causes fear and hostility. However, this negative view has been barely analysed from a linguistic perspective. In particular, this study aims to explore the semantic prosody of the Spanish lexical items inmigración (immigration) and inmigrante (immigrant) in written media. For this purpose, an ad hoc corpus of news on the phenomenon of immigration has been compiled. News between 2003 and 2013 from two national newspapers with different political ideology (El Mundo and El País) were collected. The analysis of the news was carried out with WordSmith, a corpus analysis software which enabled us to observe the co-occurrences of the words inmigrante and inmigracion. The results reveal that most of the words co-occurring with inmigrante and inmigracion have an unfavourable meaning. These results confirm those of sociological studies which have found a feeling of rejection towards the phenomenon of immigration. Therefore, our results evidence how this negative feeling is also represented in the media discourse.
\end{abstract}

Key Words: Semantic prosody, corpus, immigration, immigrant, media discourse. 


\section{Resumen}

Varios estudios, como el llevado a cabo por Checa y Arjona (2011), muestran la visión negativa de los medios de comunicación españoles hacia la inmigración desde una perspectiva social, en la que la inmigración se concibe como una amenaza y una invasión que despierta miedo y hostilidad. Sin embargo, esta visión negativa apenas se ha analizado desde una perspectiva lingüística. En concreto, en este estudio se pretende explorar la prosodia semántica de las unidades léxicas 'inmigración’ e ‘inmigrante’ en los medios de comunicación escritos. Para este propósito, se ha compilado un corpus ad hoc de noticias sobre el fenómeno de la inmigración. Las noticias seleccionadas abarcan desde el 2003 hasta el 2013 y pertenecen a dos periódicos nacionales con ideología política diferente (El Mundo y El País). El análisis de las noticias se llevó a cabo con WordSmith, un software de análisis del corpus que nos permitió observar las coocurrencias de las palabras 'inmigrante' e 'inmigración'. Los resultados ponen de manifiesto que la mayoría de las palabras que aparecen con 'inmigrante' y con 'inmigración' tienen un significado desfavorable. Estos resultados coinciden con aquellos estudios sociológicos que muestran un sentimiento de rechazo hacia el fenómeno de la inmigración. Por tanto, nuestros resultados evidencian cómo dicho sentimiento negativo también se refleja en el discurso mediático.

Palabras Clave: Prosodia semántica, corpus, inmigración, inmigrante, discurso mediático.

\section{INTRODUCTION}

Over the last two decades, various linguists (Sinclair, 1987; Louw, 1993, 2000; Stubbs, 1995, 1996, 2001a; Partington, 1998; Hunston, 2002; Schmitt \& Carter, 2004; Hoey, 2005) have been interested in the study of the semantic environment of certain items. These scholars have adopted many different approaches to the concept of semantic prosody, but they do at least seem to agree to describe it as a '(type of) meaning'. It has been defined, for example, as an 'aura of meaning' (Louw, 1993), 'halo of meaning', 'transferred meaning' (Bublitz, 1996), 'collocational prosody' (Louw, 2000; Stubbs, 2001a), 'evaluative intention' (Sinclair, 1996; Stubbs, 2001b) or the 'property of an item' (Partington, 1998; Xiao \& McEnery, 2006; Morley, 2007).

In the present study semantic prosody is conceived as an extending meaning in which an item that seems to be denotatively neutral may carry positive or negative semantic associations due to the words that frequently occur with it. Thus, semantic prosody goes beyond the mere denotative meaning of a dictionary and is an additional meaning which is capable of indicating emotional associations (Richards \& Schmidt, 2002) and even on the pragmatic or attitudinal meaning (Sinclair, 2004b). Therefore, what seems to be accepted by most theorists on this issue is that semantic prosody expresses a 'type of meaning'.

To our knowledge, previous studies on semantic prosody have focused mainly but not exclusively on the analysis of verbs. Some examples include 'break out', 'happen', 'set in' (Sinclair, 1991), 'end up' (Louw, 1993, 2000), 'accost', 'cause' (Stubbs, 1995, 
1996, 2001a), 'commit', 'peddle', 'happen', 'take place', 'occur', 'set in', 'come about' (Partington, 1998, 2004) or 'sit through' (Hunston, 2002). Other grammatical categories such as adverbs have received a degree of attention too. These are the cases of 'utterly' (Louw, 1993; Partington, 2004) and other adverbial intensifiers such as 'absolutely', 'perfectly', 'entirely', 'completely', 'thoroughly' or 'totally' (Partington, 2004). Most of these words have been explored in general corpora of language, but not in genre-specific texts compiled ad hoc such as our corpus of media texts. In addition, English has very often been the predominant language of most items, with the exception of some contrastive studies such as those published by Sardinha (2000), Tognini-Bonelli (2001), and Xiao and McEnery (2006), which compare the semantic prosody of certain items in English and Portuguese, English and Italian, and English and Chinese, respectively.

Thus, our study -which is based on the analysis of a corpus made up of news on immigration- seeks to explore the type of semantic prosody of the nouns inmigracion (immigration) and inmigrante (immigrant) present in the main Spanish written media. For the corpus analysis, WordSmith tool has been used. Finally, the study of the habitual co-text of the core items inmigración and inmigrante has enabled us to obtain their co-occurrences.

It is also interesting to mention that the phenomenon of immigration in the written media has been traditionally studied from a sociological perspective rather than from a linguistic one. This sociological perspective is based on a qualitative nature, and focuses on describing the role that media play in shaping the negative feeling towards immigration (Checa \& Arjona, 2011). We then wonder whether the language expressed in the written media represents that negative feeling of hostility, invasion or fear towards immigration.

We cannot deny that the media ideologically reproduce what happens in our societies. In fact, with regard to how the phenomenon of immigration is seen by the media, Bañón (2002) points out that the role of the media is decisive to shape public opinion on such a controversial issue as immigration. In particular, the report of the European Network Against Racism (2006-2007) indicates that the media shape a poor image of the phenomenon of immigration, which is seen as one of the main causes of racism in Spain. This negative image in the media has therefore a clear effect on how readers perceive immigration.

\section{Literature review}

\subsection{The concept of semantic prosody: Origins and perspectives}

The concept of semantic prosody has its origins in the term 'prosody' used by Firth (1957), to which he referred as a phonological colouring which spreads beyond 
semantic boundaries in the context of prosodic phonology. The term 'prosody' was borrowed by two post-Firthian corpus linguists, Sinclair (1987) and Louw (1993). However, although Sinclair (1987) was the first to observe the phenomenon of semantic prosody in the collocational behaviour of items, the concept was finally coined in linguistic studies by Louw in 1993. Since then, it has become one of the most interesting concepts in corpus linguistics. In fact, Sinclair (1991) noticed that many uses of words and phrases showed a tendency to occur in a given semantic environment. Semantic prosody is considered to be the overall discourse function of a 'unit of meaning' in a text (Hoey, 2005; Hunston, 2007).

Two perspectives towards the study of semantic prosody are distinguished: (i) the discoursal perspective and (ii) the corpus-based perspective. From the first one, semantic prosody is defined as the evaluative speaker's intention with regard to a topic, in other words, the individual speaker's attitude towards a phenomenon in a given text. According to Sinclair (2004a), this is the basic, primary choice of a speaker, and the rest of choices about that item relate to this initial choice. The second perspective, which is corpus-based, consists of analysing items that appear together many times in many texts (Sinclair, 2004a). These two perspectives are two ways of approaching the same phenomenon and can be exemplified by a wider viewpoint, 'priming', which is followed by linguists such as Hoey (2005), Xiao and McEnery (2006) or Morley (2007). Indeed, Hoey (2005) states that lexical items carry primings, that is, suggestions on how those items can be used, and prosody is one of these primings.

According to Whitsitt (2005), semantic prosody is not a univocal concept, but it has been described from three different points of view, which have provided prosody with various nuances: from a diachronic point of view (Louw, 1993; Bublitz, 1996) as opposed to a synchronic one (Sinclair, 2003), from a pragmatic perspective (Sinclair, 1996; Stubbs, 1995, 2001b) and, finally, from the point of view of its connection with connotation (Louw, 2000; Partington, 1998, 2004; Hunston, 2002).

Regarding the diachronic-synchronic axis, according to Stewart (2010), there is a tendency to use both diachronic and synchronic criteria when approaching semantic prosody, without being aware of the differences that each approach involves. As for the diachronic point of view, semantic prosody is defined as an attached meaning or as a meaning which is transferred from one word to another during the course of time (Stewart, 2010). In his critical evaluation of semantic prosody, Stewart (2010) summarizes how this phenomenon has been approached within a diachronic framework, where we can find a wide range of metaphors describing semantic prosody as a meaning transferable to an item over time:

"prosodic meaning may be attached, be taken on, be taken, be acquired, be accorded, be carried or be held; it may imbue, colour, taint, rub off, 
be reflected or spill over; further, prosodic meaning is an aura, a halo, a shade or a hue, and is the result of infection or contagion" (Stewart, 2010: 43).

This collection of metaphors is the result of several studies that have been carried out in the field of semantic prosody. For instance, Louw (1993: 157) defined semantic prosody as "a consistent aura of meaning with which a form is imbued by its collocates". Louw (1993: 164) states that "prosodies are undoubtedly the product of a long time of refinement through historical change". In the line of Louw, Bublitz (1996) pointed out that lexical items have a specific 'halo of meaning' which is able to affect nearby words and that is based on a set of collocates which may have a positive or negative semantic nuance. Other authors such as Morley and Partington (2009) agree with the diachronic dimension of semantic prosody and explain that the development of negative prosody happens with co-occurrence through time. Studies such as those conducted by Zhang (2013) and Whichmann, Simon-Vandenberger and Aijmer (2010) exemplify the diachronic nature of semantic prosody as they track the behavior of different linguistic items along time.

Although numerous scholars have defined and described semantic prosody from a diachronic perspective, only a few of them have carried out strict diachronic analyses. On the contrary, most authors have adopted a synchronic point of view, despite "briefly introducing and defining semantic prosody as the result of a diachronic phenomenon” (Stewart, 2010: 55).

As opposed to the diachronic orientation, we have adopted a synchronic approach which sees semantic prosody as an extending meaning, that is to say, as a feature which characterizes a group of items rather than a single item. Understood in synchronic terms, semantic prosody refers, as Stubbs (2001a: 65) points out, to "a feature which extends over more than one unit in a linear string". In this sense, semantic prosody is described as a meaning which "belongs to or is distributed over a unit of language" (Stewart, 2010: 53), ranging over several units or combinations of words (Sinclair, 2003). Our analysis therefore focuses on semantic prosody as a synchronic process in which the meaning is extended over groups of words.

As far as the pragmatic perspective is concerned, Sinclair (1996) claims that semantic prosody has a functional character. In particular, it has a pragmatic and attitudinal function, which normally constitutes the speaker's reason for making the utterance. Put another way, it is not lexico-grammatical patterns that we can find in language, but also pragmatic patterns of language use. Semantic prosody can therefore reveal the writer's position or attitude towards certain lexical items as well as his/her communicative purpose. 
Along the same lines, Stubbs (2001a) underlines the pragmatic and discourse function of semantic prosody, so he prefers the term 'discourse prosody'. In fact, Stubbs (2001a: 65) underlines the attitudinal nature of semantic prosody by stating that:

“discourse prosodies express speaker's attitude. [...] Since they are evaluative, prosodies often express the speaker's reason for making the utterance, and therefore identify functional discourse units".

Nonetheless, Bednarek (2008) warns that semantic prosody cannot always be identified as a pragmatic element. The author continues explaining that collocational clashes can only result in pragmatic meanings when items exhibit "a very strong preference" (Bednarek, 2008: 127) for negative or positive meanings. Consequently, we have to bear in mind that semantic prosody is not a "pragmatic backdrop" (Sorli, 2013: 108). In Sorli's words, it has to be understood as "a result of empirically identifiable elements of the meaning structure" (Sorli, 2013: 108).

Louw (2000) amplifies his definition of semantic prosody as 'aura of meaning' and considers it as something distinguishable from connotation. In the context of semantic prosody, connotation is understood as evaluative meaning. Connotation is frequently identified as semantic prosody (Sinclair, 2003). Thus, connotation and semantic prosody can be closely related but they should be considered different phenomena. Connotation is more obvious and consistent, as well as related to individual items, whereas semantic prosody is less evident and more prone to changing with context:

"the latter is expressed over stretches of discourse, whilst by and large lexicographers [...] find it easy and natural to think in terms of individual word meaning" (Morley \& Partington, 2009: 151).

In order to distinguish these two linguistic phenomena, Morley and Partington (2009: 151) define connotation in terms of prototypicality:

"The items closer to the centre [understood here as the prototype] are those with the most evident and consistent evaluative connotation, whilst those closer to the outskirts have an evaluative connotation which is less obvious and consistent and which is perhaps more likely to be switched off or overturned when contextual requirements demand".

Louw (2000) claims that while semantic prosody depends on the co-text and thus can be explored in a corpus through regular co-occurrences of an item, connotation is related to instinctive semantic associations that are often made of an item, regardless of the collocates.

Semantic prosody should not be confused with semantic preference, although the terms are closely related (Partington, 2004; O’ Halloran, 2007; Bednarek, 2008). 
Scholars such as Sorli (2013), Hoey (2005) or Philip (2009) argue that meaning is structured on different levels of abstraction, semantic prosody being the most abstract, followed by what they call semantic preference. In Sorli's words (2013), semantic preference is to be distinguished from semantic prosody. Although neither is directly observable, the former "can be stated upon the examination of the preferred lexis" (Sorli, 2013: 101). Within Sinclair's model (2004a: 33), semantic preference refers to the words an item co-occurs with, since "some words prefer, or even require, a semantic profile of the words with which they combine" (Dam-Jensen \& Zethsen, 2008: 206). Semantic prosody, however, refers to relations that involve evaluative meaning or evaluative prosodic patterns. Therefore, according to Partington (2004), it could be said that semantic preference is a 'narrower' phenomenon than semantic prosody since the former relates the node item to another item from a particular group of words and the latter affects wider stretches of text. Within Sinclair's unit of meaning (1996), as far as collocation is concerned, it is not related to the evaluative meaning or the pragmatic function which is given by the writer or speaker to a certain item, but to the other lexical items the node co-occurs with regularly.

In this study, we explore the semantic prosody from a synchronic perspective, as we do not scrutinize the origins of the terms inmigracion and inmigrante.

\subsection{Types of semantic prosody}

The semantic prosody of a lexical item is commonly classified in three different categories: positive, negative and neutral. Other evaluative labels have been used in the literature: favourable and unfavourable, desirable and undesirable, pleasant and unpleasant. Indeed, Xiao and McEnery (2006: 108) point out that:

"A pleasant or favourable affective meaning was labelled as positive while an unpleasant or unfavourable affective meaning was judged as negative. When what was happening was completely neutral, or the context provided no evidence of any semantic prosody, the instance was labelled as neutral."

McEnery and Hardie (2012: 135) highlight the fact that an item can have a positive or negative prosody and note that "words or phrases are said to have a negative or positive semantic prosody if they typically co-occur with units that have a negative or positive meaning". Regarding the type of prosody, most authors who have examined this phenomenon have identified many more negative examples than positive ones of semantic prosody. Thus, Louw (2000) states that words characterised by negative semantic prosodies are more frequent than positive ones. In the list of lexical items compiled by McEnery, Xiao and Tono (2006), only three examples of positive prosody (build up to, provide, career) are identified against the numerous cases of negative prosody (break out, happen, set in, bent on, cause, fan the flame, commit, peddle, etc.). 
Furthermore, when semantic prosody occurs in specific text types or specific subject areas, it is called 'local prosody' (Tribble, 2000). This prosody only appears with items in specific-genre texts, that is, local prosody is that prosody which specifically occurs in a given text genre and therefore out of it the prosody may change or even not occur. Local prosody is the one that is to be applied to our study, in which the prosody of the items inmigracion and inmigrante is examined in the journalistic genre and not generally. While positive, negative and neutral semantic prosodies lie upon the axis of different forms of 'badness' or 'goodness' of an item, local prosody is strongly related to the particular context or genre in which the node item is found and combined with its collocates.

\subsection{Methodological study of semantic prosody}

Methodologically speaking, many authors claim that semantic prosody should be examined by means of computational methods (Fox, 1998; Channell, 1999; Widdowson, 2000; Hoey, 2005). According to Stubbs (1995), in the study of semantic prosody attested data from the exploration of a corpus should be used and not a native speaker's intuitions, which are unreliable for this type of studies. In addition, Hunston (2002) states that semantic prosody can only be delimited if a large number of examples of a lexical unit are observed and this is possible through the use of corpus analysis tools. Sinclair (2003) also recommends that semantic prosody should be explored through corpus-analytic techniques for it allows us to see how words cooccur to make special meanings which are not so much related to the dictionary but to preference and evaluation. Louw (2000) argues that mere introspection is not enough, semantic prosody being a phenomenon related to co-occurrence. Francis and Sinclair (1994) claim that corpus linguistics offers incontrovertible evidence to the research on semantic prosody as it enables to examine in a split second huge amount of language. That is why Louw and Chateau (2010: 756) warn that this linguistic phenomenon is "not available to a priori intuition".

Thus, intuition and introspection may not be enough, but that does not mean that they should be discarded. In fact, Stewart (2010) suggests that there is no empirical evidence that semantic prosody cannot be intuitively or introspectively reached. This author advocates for a role of intuition and introspection in the study of semantic prosody: “[...] we should perhaps think twice before stigmatizing intuition and introspection as inaccurate and unreliable by comparison with corpus data" (Stewart, 2010: 134). The author continues explaining that corpus searches and finds do not simply happen, but are triggered by "moments of intuition and introspection" (Stewart, 2010: 135).

Nonetheless, the two perspectives developed above do not have to oppose each other. McEnery and Wilson (2001) do not consider intuition and the corpus-based approach mutually exclusive but complementary. Zhang (2013) does not question this 
idea but he highlights that semantic prosody is less accessible only through intuition, and computation would contribute to a better and more complete approach towards semantic prosody: "it is computational research and corpus linguistics that make it possible to highlight its existence" (Zhang, 2013: 64).

\subsection{The study of the phenomenon of immigration from a linguistic perspective}

Denotatively speaking, the words inmigración and inmigrante show no negative or hostile nuance. In fact, as evidenced by the Diccionario de la Real Academia Española (DRAE, 2001), inmigración is defined as "acción de llegar a otro país diferente al propio para establecerse en él, especialmente con la idea de formar nuevas colonias o domiciliarse en las ya formadas" [action of reaching a different country to settle in it, especially with the idea of forming new colonies or settling in those already formed]. Inmigrante refers to the person (immigrant) who does this action. According to these definitions, immigration and immigrant are apparently neutral words, devoid of semantic burden indicating hostility, threat or rejection. However, the concept of immigration represented in the Spanish media seems to differ from that defined by the DRAE (2001) and it acquires certain semantic nuances that show a negative image of this phenomenon. This negative image shaped by the media has been explored from a linguistic perspective through some studies such as those carried out by Martínez Lirola (2008), Crespo Fernández and Martínez Lirola (2012), and LópezMaestre and Scheu-Lottgen (2003).

The first two studies explore the phenomenon of immigration from the perspective of Critical Discourse Analysis and Visual Grammar. Therefore, both studies make use of both linguistic features (headline, written text, collocations and emphatic expressions, use of the passive voice, verbs) and visual features (background, image size, frames, body position, facial expression or colours) present in multimodal texts (combining verbal and non-verbal modes) on immigration. The first study (Martínez Lirola, 2008) includes two texts on immigration published in a local newspaper of the province of Alicante, while the second (Crespo Fernández \& Martínez Lirola, 2012) is based on a corpus of eight multimodal texts about immigration as well. We believe that the collected corpora are limited in terms of size and, in this regard, Crespo Fernández and Martínez Lirola (2012: 30) state that:

"the number of newspapers that constitute our corpus do not allow us to reach valid conclusions in quantitative terms. Our analysis follows the tradition of critical discourse analysts, who have usually relied on small data samples". 
In both studies the authors conclude that immigrants tend to be represented i) as a threat and a burden to society; ii) as poor and illegal people living in a dramatic situation and iii) as workers who seek livelihood and to be accepted by the Spanish society.

The study conducted by López-Maestre and Scheu-Lottgen (2003) focuses on examining the discourse on immigration from the perspective of Critical Discourse Analysis and Discursive Psychology. In particular, the authors explore how the phenomenon of immigration is perceived by a group of students of English Philology at the University of Murcia. For this purpose, this group of students was asked to express their attitudes on immigration through the writing of an essay on this issue. The results revealed that a problematic view on immigration prevailed, since it was conceptualized as a problem of political, economic, social and cultural dimensions to the host society. In fact, immigrants were seen by most participants as a massive threat and as an invasion of people difficult to control.

The three studies reviewed have in common the use of an interdisciplinary approach in which Critical Discourse Analysis is combined with Visual Grammar and Discursive Psychology respectively. They are studies focused on the social character of all discourse and interested in exploring the connection between language, attitude and ideology. However, as it has been already mentioned throughout the literature review, semantic prosody has a functional nature which is capable of revealing the writer's attitude towards certain lexical items through the exploration of their co-occurrences. This linguistic perspective fits, therefore, the aim of the present work.

\section{Aim of study}

This study primarily aims to explore the type of semantic prosody of the Spanish nouns inmigración (immigration) and inmigrante (immigrant) present in the written media. Given the social relevance of this phenomenon in the current situation of Spain, we also intend to examine whether this negative general feeling towards immigration is represented through the language expressed in the Spanish written media.

\section{Method}

\subsection{Corpus description}

The corpus compiled for the present study contains 278,836 words. It is based on articles on immigration from two well-known Spanish newspapers: El Mundo and El País. They are the most widely read in Spain and both are written in Spanish. Although similar in importance, they differ in ideology. El Mundo was created in 1989 by Pedro J. Ramírez. It is conservative and it belongs to the centre-right wing. El País is progressive and it is classified as centre-leftist. It appeared for the first time in 1976 under the supervision of PRISA corporation group. According to the last report by La 
Oficina de Justificación y Difusión (2012), these newpapers are the most widely distributed and read in Spain.

The number of words provided by the two newspapers for our corpus is similar with 139,627 from El País and 139,209 from El Mundo. The searching procedure was carried out in the digital library of each newspaper. The time span for the articles selection includes 10 years, from 2003 to 2013. We decided to explore this decade for two reasons: firstly, the phenomenon of immigration in Spain started to grow dramatically at the beginning of the 21st century; and secondly, our study pursues to offer a contemporary, present-day view of the linguistic items analysed.

\subsection{Procedure}

The corpus was run by the software Wordsmith, which allowed us to observe how words behaved. In order to eliminate all non-informing or potentially misleading words, we used a 'stoplist' which contained highly common words such as determiners or conjunctions. Therefore, this type of words was filtered out prior to text processing. Special mention has to be made to the preposition contra (against). The 'stoplist' that was applied in our analysis initially contained all prepositions, but we decided not to include contra due to the specific weight that it might have for this specific purpose, and given the social bent of our study. In fact, words such as contra may be considered semi lexical terms. Sometimes, the distinction between functional words and lexical words is too simple to categorize some linguistic items. This is the case of contra, which is placed within the functional category of prepositions; however, it displays a strong negative meaning which should not be ignored (Corver \& van Riemsdijk, 2001).

Wordsmith offers the terms that co-occur with the selected nodes, in this case inmigracion and inmigrante. Hoey (2005: 158) suggests that semantic prosody should be studied "within a fairly restricted window". Thus, in order to be as accurate as possible, we narrowed down and we limited our research to the three closest right and left words to the nodes inmigracion and inmigrante. We limited our analysis to the words that occurred ten or over ten times. We considered that this figure is quite significant, taking into account that the window is the three closest words to the nodes.

Inflected forms, namely plural, verb tenses or $-\mathrm{s}$ third singular person were counted just as one single lexical unit. However, derivational forms, that is to say, those that contain semantic affixes such as prefixes or suffixes, were counted separately. We consider that inflection does not essentially change the meaning of a stem. However, derivation, which is the use of prefixes and suffixes, does imply a change of meaning. 


\section{Results}

The words inmigracion and inmigrante are the two items (content words) that occur more frequently in our corpus with 1,992 times and 1,936 times respectively, the number of occurrences of the two words being very similar. Inmigración occurs 1,014 times with a content word in a close position (L3-L1 and R1-R3 position), whereas the co-occurrence of inmigrante with a content word points to 912 times. A significant number of negative words occur with the terms inmigracion and inmigrante.

In the case of inmigración, we found 62 words with a negative meaning, namely batalla (battle), crisis (crisis), explotación (exploitation), guerra (war), hostilidad (hostility), problema (problem) or preocupación (worry), among others. The total number of negative lexical items that co-occur with inmigrante is significantly higher with up to 106 . What is more, some of the negative words such as ilegal (illegal) or contra (against) occur with both inmigración and inmigrante.

Table 1 shows the top negative lexical units that occur with inmigracion. Words are ordered according to their number of occurrences. As can be observed, some of them occur over 100 times. This is the case of the three first top terms: ilegal (illegal), contra (against) and lucha (fight). The negative term at the top is ilegal with 386 occurrences. This is followed by contra co-occurring with inmigracion 218 times. Lucha is also worth mentioning here with 119 co-occurrences.

It is also interesting to mention that some of the words occur in a specific position due to their own nature. This is the case of combatir (combat) or frenar (stop), which appear in L2, as they are transitive verbs, and forming combatir la inmigración and frenar la inmigración. Some other words such as contra (against), control (control), frente (opposite), ilegal (illegal), medida (measure) or lucha (fight) lean towards a specific position. For instance, contra occurs 211 out of 218 in L2 position with respect to the node inmigración, giving place to the chunk contra la inmigracion. In fact, this chunk is completed with other top words such as lucha or frente, prompting lucha contra la inmigración and frente a la inmigración.

Table 1. L3-R3 position of top negative words with inmigración.

\begin{tabular}{|c|c|c|c|c|c|c|c|c|}
\hline Lexical unit & Total occurrences & L3 & L2 & L1 & Node & R1 & R2 & R3 \\
\hline Ilegal & 386 & 1 & 0 & 0 & Inmigración & 382 & 0 & 3 \\
\hline Contra & 218 & 3 & 211 & 0 & Inmigración & 0 & 3 & 1 \\
\hline Lucha & 119 & 118 & 1 & 0 & Inmigración & 0 & 0 & 0 \\
\hline Problema & 73 & 58 & 2 & 0 & Inmigración & 0 & 0 & 13 \\
\hline Control & 48 & 30 & 14 & 0 & Inmigración & 0 & 0 & 4 \\
\hline Frenar & 25 & 0 & 25 & 0 & Inmigración & 0 & 0 & 0 \\
\hline Delito & 23 & 4 & 15 & 0 & Inmigración & 0 & 1 & 3 \\
\hline Delincuencia & 19 & 4 & 2 & 0 & Inmigración & 0 & 13 & 0 \\
\hline Frente & 18 & 16 & 0 & 0 & Inmigración & 1 & 1 & 0 \\
\hline Medida & 18 & 15 & 1 & 0 & Inmigración & 0 & 2 & 0 \\
\hline Combatir & 17 & 0 & 17 & 0 & Inmigración & 0 & 0 & 0 \\
\hline Negativa & 13 & 4 & 3 & 0 & Inmigración & 0 & 6 & 0 \\
\hline
\end{tabular}


As regards inmigrante, Table 2 shows the top lexical units which were found to occur with this node. As in Table 1, the first word, which is ilegal, is the one that occurs most with inmigrante with 105 times. Table 2 shows the top negative lexical units that occur with inmigrante. It is important to note the great difference between this first word and the second one masivo (massive), which co-occurs 41 times, and the third one avalancha (avalanche) with 26 times. As in the case of inmigracion, some of the terms accompanying inmigrante appear in a specific position, suggesting linguistic chunks that are repeated along the corpus. For instance, the word ilegal occurs with inmigrante 90 times out of 105 in R1 position bringing about the chunk inmigrante ilegal, so that inmigrante frequently implies being outside the law. The word avalancha is another example. A similar case is found in clandestino (also illegal), occurring with inmigrante 16 times in R1 position, and consequently with minor representation of the chunk inmigrante clandestino.

Other negative terms form noun phrases with inmigrante. The word avalancha occurs 26 times with inmigrante, adopting the L2 position, except for one occasion. This fact indicates that avalancha is part of a recurrent linguistic chunk found in news about immigration, namely avalancha de inmigrantes. Similarly, we find the word ola (wave) which co-occurs with inmigrante 18 times in the corpus, forming the chunk ola de inmigrantes. Despite the fact that words such as avalancha, ola, devolución or interceptar do not bear so obvious negative meaning, they have been considered to be negative in this study (see Discussion section).

Table 2. $\mathrm{L}_{3}-\mathrm{R} 3$ position of top negative words with inmigrante.

\begin{tabular}{|c|c|c|c|c|c|c|c|c|}
\hline Lexical unit & Total occurrences & L3 & L2 & L1 & Node & R1 & R2 & R3 \\
\hline Ilegal & 105 & 1 & 8 & 2 & Inmigrante & 90 & 2 & 2 \\
\hline Masivo & 41 & 3 & 38 & 0 & Inmigrante & 0 & 0 & 0 \\
\hline Avalancha & 26 & 0 & 25 & 0 & Inmigrante & 0 & 0 & 1 \\
\hline Contra & 22 & 1 & 11 & 6 & Inmigrante & 3 & 1 & 0 \\
\hline Expulsar & 22 & 17 & 3 & 0 & Inmigrante & 1 & 1 & 0 \\
\hline Detener & 20 & 2 & 8 & 0 & Inmigrante & 4 & 6 & 4 \\
\hline Ola & 18 & 1 & 16 & 0 & Inmigrante & 0 & 1 & 0 \\
\hline Clandestino & 17 & 1 & 0 & 0 & Inmigrante & 16 & 0 & 0 \\
\hline Interceptar & 16 & 6 & 3 & 0 & Inmigrante & 3 & 2 & 2 \\
\hline Muerte & 13 & 4 & 0 & 0 & Inmigrante & 6 & 1 & 2 \\
\hline Asalto & 11 & 2 & 4 & 0 & Inmigrante & 1 & 1 & 3 \\
\hline
\end{tabular}




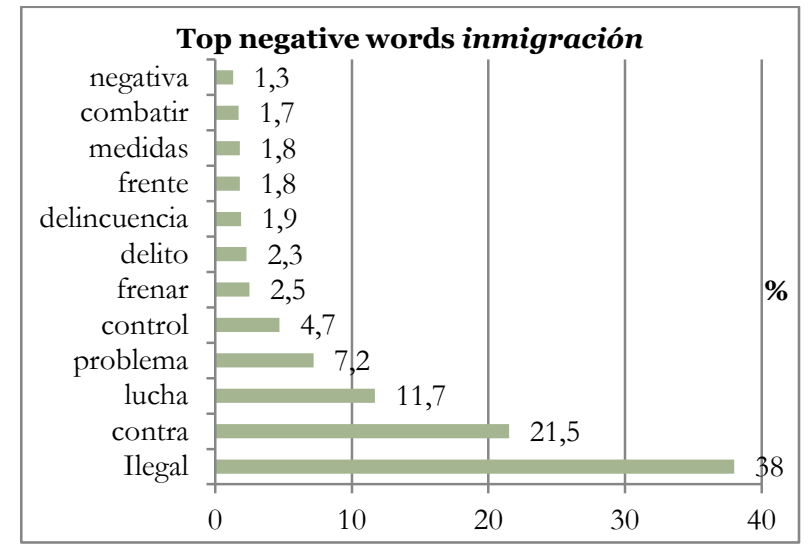

Figure 1. Percentage of top negative words occurring with inmigración.

As stated previously, the number of times inmigracion occurs with a content word reaches 1,014 occurrences. Taking into consideration the number of occurrences of the negative top words accompanying inmigracion, we can state that every 100 times inmigracion co-occurs with a content word, it appears 38 times with ilegal, 21,5 with contra and over 7 with lucha (see Figure 1). What is more, regarding the sum of percentages of the negative top words, we could state that inmigracion presents a negative prosody in over $65 \%$ of its occurrences. Likewise, inmigrante occurs 912 times with a lexical item in L3-L1 and R1-R3 position. In this case every 100 times this happens it co-occurs almost 12 times with ilegal, over 4 with masivo and 3 with avalancha, which implies that inmigrante presents a negative prosody in $20 \%$ of the occasions (see Figure 2).

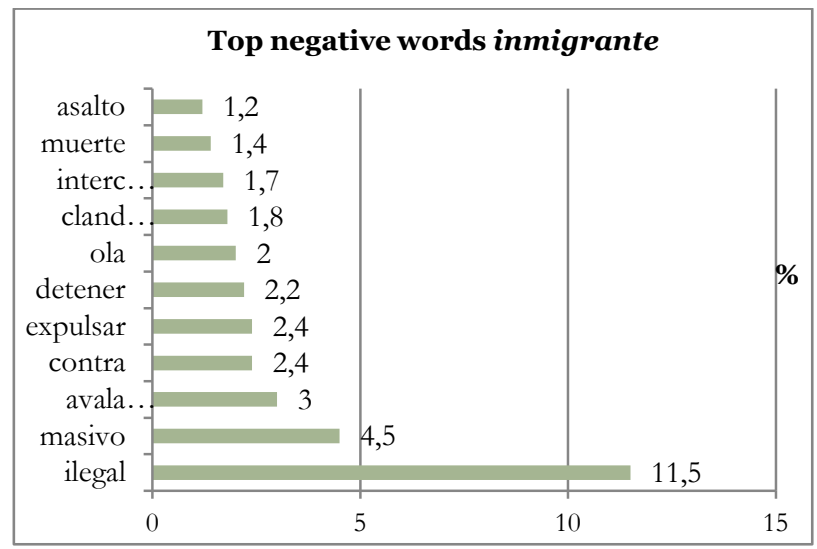

Figure 2. Percentage of top negative words occurring with "inmigrante".

Our analysis has focused on the words that occur at least 10 times with inmigracion and inmigrante, but there are many others that occur under 10 times, but which are also worth mentioning here due to their high negative burden. This is the case of crimen (crime), inseguridad (insecurity) or rechazar (reject), which co-occur with inmigración up to 
nine times, or drama (drama) or masiva (massive) which co-occur 8 times. In the case of inmigrante, words such as devolución (return) or rechazo (rejection) occur 7 and 6 times respectively. This number of times hardly represents $1 \%$ of the close co-occurrences with inmigracion and inmigrante, but they involve high negative burden.

\section{Discussion}

In our study, the most frequent occurrence for both inmigracion and inmigrante is ilegal, which was used 38\% with inmigracion and 11,5\% with inmigrante. These significant percentages show that the newspapers under study pay considerable attention to the illegality of the phenomenon of immigration and are focused on the lack of legal authorisation to remain in the country in which immigrants reside. In this sense, our results can be comparable to those obtained by The Migration Observatory at the University of Oxford in its Report on Migration in the News (2013), in which one of the most noteworthy patterns was the prominence of the phrase 'illegal immigrants'. However, as this Report points out, although:

"illegal far outnumbered any other modifier of immigrants [...], it is worth noting that immigrants with legal status far outnumber those without it, according to the best estimates of the size of both types of migrant populations" (2013: 24).

Other corpus-based studies (Baker, Gabrielatos, Khosravinik, Krzyzanowski, McEnery \& Wodak, 2008; Taylor, 2009) share the idea that the phenomenon of immigration is often represented in the press negatively. In their analysis of a 140million-word corpus of British news articles about refugees, asylum seekers, immigrants and migrants (RASIM), Baker et al. (2008) establish eight categories of reference to classify their observations ${ }^{1}$ and state that "these categories are regularly used in ways which negatively reference RASIM" (2008: 286), being the newspapers' attitude towards RASIM negative rather than positive. Later on, Taylor (2009) carried out a corpus-assisted study to explore the representation of foreign migrants in the Italian press. Her work was a para-replication of the Lancaster group's research into RASIM. Taylor observed that the node items immigrati, clandestini, extracomunitari and stranieri were also frequently constructed negatively in the Italian newspapers.

The studies by Baker et al. (2008) and Taylor (2009), carried out in UK and Italy respectively, evidence that this type of negative vision is not exclusive to the Spanish press but it is also present in the press of other countries.

The co-occurrence contra (against) is also referred to both nodes, and its meaning reads "denota la oposición y contrariedad de una cosa con otra" (DRAE, 2001), and it is with this meaning that is presented in our corpus. Contra appears in sentences like "Cresson presenta un plan de guerra contra la inmigración clandestina". It is fair to clarify that being against something may have a positive result, for instance 'being 
against domestic violence' is good for society and it is considered a good attitude towards that issue. However, in the linguistic construction 'being against something' [estar contra algo], the concept found after contra indicates that concept is negative. In the expression estar contra la violencia de género, contra indicates that violencia de género is being opposed, having violencia de género a negative meaning. Indeed, violencia de género has a denotatively negative meaning. By the same token, we find examples such as 'being against pollution' or 'against racism', pollution and racism being also considered denotatively negative. Contra acts in the same way with other concepts which are not so clearly negative. Yet, if we analyse a more neutral word such as government or technology in being against the government or being against technology, these words are understood as negative terms in these expressions, although technology or government are not denotatively negative. However, it cannot be ignored that this seems to be one of the unresolved dilemmas in studies on semantic prosody, i.e., the parameter or the criterion with which the prosody should be inferred: is the concept denoted by the co-occurrence unpleasant in the mind of the person who produces the utterance, or is it a generally unfavourable concept?

Other three co-occurrences that require attention are lucha (fight), problema (problem) and delito (crime). These three words are associated with negative situations and are found in sentences like "las autoridades marroquíes están colaborando muchísimo en la lucha contra la inmigración ilegal"; "las autoridades marroquíes abordarán el problema de la inmigración irregular"; or "el partido que más insistió en tipificar como delito la inmigración irregular".

Moreover, immigration is seen as a growing and uncontrollable phenomenon that must be fought and stopped. In fact, control (control), frenar (stop) and combatir (combat) are common words found in the co-text of the node inmigracion. This idea is present in sentences such as "la tecnología del siglo XXI tiene que aportar soluciones para el control de las fronteras"; "la instalación de cuchillas no va a frenar la llegada de inmigrantes"; or "Sarkozy ha lanzado varias propuestas para combatir la delincuencia y la inmigración ilegal". Similarly, other words such as interceptar or detener have also been considered to convey a negative prosody to the nodes inmigracion and inmigrante. Having a look at the CREA (Spanish Royal Academy Corpus), the twenty five first examples of both terms co-occur with words representing negative concepts. Detener appears with items such as pandemia, oleada de protestas, el avance de la enfermedad, la limpieza étnica, la guerra, los ataques, los combates. In the case of interceptar, we find a similar picture, with this item co-occurring with la fuga, cinco toneladas de cocaina, unos delincuentes muy peligrosos. The definition of detener and interceptar may not be denotatively negative in isolation, but their behaviour in context points to negativity. If we talk about detener la inmigración or interceptar inmigrantes, we are transmitting the idea of immigration and immigrant as something negative preventing the phenomenon from developing. 
The node inmigrante(s) tends to co-occur with words such as masivo (massive), avalancha (flood) and ola (wave). These three words, which describe an excessive amount of something, are found in sentences such as "la llegada masiva de pateras a la zona del Estrecho de Gibraltar no cesa"; "la avalancha de inmigrantes en Canarias sigue con la llegada de nuevas barcazas"; or "Alemania ha recibido su mayor ola de inmigrantes desde 1995". In this sense, Baker et al. (2008: 287) also observe that a common strategy was to quantify immigrants in terms of water metaphors (pour, flood, stream), which tend to represent them as "an out-of-control, agentless, unwanted natural disaster".

Ola has already been mentioned by The Report 'Migration in the News' offered by the Migration Observatory at the Oxford University (2013). This report offers a wide view of items such as 'immigrant' and 'immigration' as seen by the UK press. Ola (wave) and avalancha (flood) appear very frequently in the company of immigrant and immigration, data that are highlighted in the report, relating immigration and immigrant to mass entry. A literal definition of these two words refers to natural phenomena. The use of these words mirrors the idea of immigration as a violent occupation.

All these examples contribute to the idea that immigrants are a massive group of people who 'invade' a territory, are expelled, arrested or intercepted. In fact, the node inmigrante often co-occurs with verbs like expulsar (expel), detener (arrest) and interceptar (intercept). These three verbs are found in sentences such as "la ley quiere dotarse de armas para expulsar a los inmigrantes sin papeles"; "tras la avalancha, la policía ha logrado detener a cerca de 50 inmigrantes"; or "la policía hace redadas para interceptar a estos inmigrantes".

The linguistic results obtained here are in the line of different sociological studies on the phenomenon of immigration. Thus, the last sociological study about immigration published by the CIS (Spanish Centre of Sociological Research) in 2011 explored the Spanish people's attitudes towards this phenomenon. It reveals that over $8 \%$ of the population considers immigration the biggest problem of the country, even more serious than gender violence, drugs or corruption. These data are interesting given the fact that the big economic crisis in which we are immersed had already started in 2011. According to the CIS, over 60\% think that immigrants receive a lot of help or enough help and protection on the part of the government. The negative semantic prosody shown by our results and therefore mirrored by linguistic behaviour is in line with the answer to one of the CIS questions: what is the first thing that comes to your mind when you hear the word immigration? Up to $43 \%$ of the respondents' answers implied negative concepts as they associated immigration and immigrants to negative words such as poverty, inequality, illegal, irregular, dramatically increasing number of immigrants, problems, crime and negative feelings in general. In 
fact, words such as ilegal (illegal), problema (problem) or delito (crime) are among the most representative of the semantic prosody of our two nodes.

\section{CONCLUSION}

A certain feeling of social uneasiness and untruthfulness triggered by the phenomenon of immigration has been mirrored in the press language. This negativity has been corroborated by the negative semantic prosody extended to the words inmigracion and inmigrante in the specific genre of the written media. A significant number of examples have been found where denotatively negative terms accompany these two words. Therefore, our study shows how language -unintentionally or notreflects a social feeling about a polemic present-day phenomenon as immigration.

The present study has focused on the Spanish language but we wonder whether this negative semantic prosody about the words inmigracion and inmigrante can be inferred for their equivalents in other languages and other genres. Another interesting issue involves analysing the degree of negative semantic prosody by establishing a comparison between the two newspapers, one being liberal and the other conservative. All these questions open a research line in the area of Semantics.

The main limitation of the current study is some of the co-occurrences that have been considered for our analysis. We acknowledge that words such as masivo, avalancha or ola can be positive in ola de entusiasmo or avalancha de felicidad. However, they have been interpreted as negative in the context of immigration. The main reason is that they have been previously included in studies about immigration as something that contributes to the negative attitude towards this phenomenon. In fact, our results seem to be in the line of previous studies, confirming that these words extend a negative meaning to the nodes in question. The proposed methodology focuses exclusively on neutral to unfavourable co-occurrences, which are the only ones accompanying the nodes inmigracion and inmigrante in our corpus. In fact, none of the articles forming our corpus reports a pleasant or positive reality on immigration in Spain, but an unpleasant phenomenon associated to illegality, crime, and something out of control that must be stopped. 


\section{BIBLIOGRAPHICAL REFERENCES}

Baker, P., Gabrielatos, C., Khosravinik M., Krzyzanowski M., McEnery, T. \& Wodak, R. (2008). A useful methodological synergy? Combining critical discourse analysis and corpus linguistics to examine discourses of refugees and asylum seekers in the UK press. Discourse \& Society, 19(3), 273-306.

Bañón, A. M. (2002). Discurso e inmigración. Propuestas para el análisis de un debate social. Murcia: Universidad de Murcia.

Bednarek, M. (2008). Semantic preference and semantic prosody re-examined. Corpus Linguistics and Linguistic Theory, 4(2), 119-139.

Bublitz, W. (1996). Semantic Prosody and Cohesive Company: Somewhat Predictable. Leuvense Bijdragen, 85, 1-32.

Channell, J. (1999). Corpus-based analysis of evaluative lexis. In S. Hunston \& G. Thompson (Eds.), Evaluation in Text: Authorial Stance and the Construction of Discourse (pp. 38-55). Oxford: Oxford University Press.

Checa, J. C. \& Arjona, Á. (2011). Españoles ante la inmigración: El papel de los medios de comunicación. Comunicar, 37, 141-149.

CIS (2011). Centro de Investigaciones Sociológicas. Actitudes hacia la inmigración [on line]. Retrieved from: http://www.cis.es/cis/opencm/ES/1_encuestas/estudios/listaMuestras.jsp?e studio $=13264$

Corver, N. \& van Riemsdijk, H. (2001). Semi-lexical categories: The function of content words and the content of function words. Berlin: Mouton de Gruyter.

Crespo Fernández, E. \& Martínez Lirola, M. (2012). Lexical and visual choices in the representation of immigration in the Spanish press. Spanish in Context, 9, 2757.

Dam-Jensen, H. \& Zethsen, K. K. (2008). Translator awareness of semantic prosodies. Target, 20(2), 203-221.

European Network Against Racism (2006-2007). Informe anual 2006 y 2007 Sobre el racismo en el Estado español [on line]. Retrieved from: http://www.enareu.org/Reports-153

Firth, J. R. (1957). A synopsis of linguistic theory, 1930-1955. In J. R. Firth et al. (Eds.), Studies in Linguistic Analysis. Special volume of the Philological Society (pp. 132). Oxford: Blackwell. 
Fox, G. (1998). Using corpus data in the classroom. In B. Tomlinson (Ed.), Materials Development in Language Teaching (pp. 25-43). Cambridge: Cambridge University Press.

Francis, G. \& Sinclair, J. (1994). 'I bet he drinks Carling Black Label': A Riposte to Owen on Corpus Grammar. Applied Linguistics, 15(2), 190-200.

Hoey, M. (2005). Lexical Priming. A new theory of words and language. London: Routledge.

Hunston, S. (2002). Corpora in Applied Linguistics. Cambridge: Cambridge University Press.

Hunston, S. (2007). Semantic prosody revisited. International Journal of Corpus Linguistics, 12(2), 249-268.

López-Maestre, M.D. \& Scheu Lottgen, D. (2003). Student's Discourse on Immigration Attitudes and Ideological Values: A Critical View. International Journal of English Studies, 3, 209-233.

Louw, B. (1993). Irony in the Text or Insincerity in the Writer? The Diagnostic Potential of Semantic Prosodies. In M. Baker, G. Francis \& E. TogniniBonelli (Eds.), Text and Technology: In Honour of John Sinclair (pp. 157-175). Amsterdam: John Benjamins.

Louw, B. (2000). Contextual Prosodic Theory: Bringing Semantic Prosodies to Life. In C. Heffer, H. Sauntson \& G. Fox (Eds.), Words in Context: A Tribute to John Sinclair on his Retirement (pp. 48-94). Birmingham: ELR.

Louw, B. \& Chateau, C. (2010). Semantic prosody for the 21st century: Are prosodies smoothed in academic contexts? A contextual prosodic theoretical perspective. In Proceedings of 10th International Conference on Statistical Analysis of Corpus Study (pp. 755-764).

Martínez Lirola, M. (2008). Las relaciones entre las características lingüísticas y visuales de las noticias sobre inmigración en la prensa gratuita y su relación con la audiencia. Discurso \& Sociedad, 2, 799-815.

McEnery, T. \& Hardie, A. (2012). Corpus Linguistics: Method, Theory and Practice. Cambridge: Cambridge University Press.

McEnery, T. \& Wilson, A. (2001). Corpus Linguistics. Edimburgh: Edimburgh University Press.

McEnery, T., Xiao, R. \& Tono, Y. (2006). Corpus-based Language Studies. London and New York: Routledge. 
Morley, J. (2007). Ask not for whom Big Ben bongs: It tolls for ITV. In L. Jottini, G. del Lungo \& J. Douthwaite (Eds.), Cityscapes: Islands of the Self (pp. 23-42). Cagliari: Cooperativa Universitaria Editrice Cagliaritana.

Morley, J. \& Partington, A. (2009). A few Frequently Asked Questions about semantic -or evaluative- prosody. International Journal of Corpus Linguistics, 14(2), 139158.

O'Halloran, K. (2007). Critical discourse analysis and the corpus-informed interpretation of metaphor at the register level. Applied Linguistics, 28, 1-24.

OJyD (2012). Oficina de Justificación y Difusión [on line]. Retrieved from: http://www.ojd.es/

Partington, A. (1998). Patterns and Meanings: Using Corpora for English Language Research and Teaching. Amsterdam: John Benjamins.

Partington, A. (2004). Utterly Content in Each Other's Company: Semantic Prosody and Semantic Preference. International Journal of Corpus Linguistics, 9, 131-156.

Philip, G. (2009). Why prosodies aren't always present. Insights into the idiom principle. Proceedings of the Corpus Linguistics Conference, University of Liverpool, Liverpool.

Real Academia Española (2001). Diccionario de la lengua española (22.a ed.). Madrid: España.

Richards, J. C. \& Schmidt, R.W. (2002). Longman Dictionary of Language Teaching and Applied Linguistics ( $3^{\text {rd }}$ edn.). Harlow, Essex and London: Pearson Education/Longman.

Sardinha, T. (2000). Semantic prosodies in English and Portuguese: A contrastive study. Cuadernos de Filología Inglesa, 9, 93-109.

Schmitt, N. \& Carter, R. (2004). Formulaic Sequences in Action: An Introduction. In N. Schmitt (Ed.), Formulaic Sequences: Acquisition, Processing and Use (pp.1-22). Amsterdam: John Benjamins.

Sinclair, J. (1987). Looking up. London: Collins COBUILD.

Sinclair, J. (1991). Corpus, concordance, and collocation. Oxford: Oxford University Press.

Sinclair, J. (1996). The Search for Units of Meaning. Textus, 9, 75-106.

Sinclair, J. (2003). Reading Concordances. Harlow: Pearson Education. 
Sinclair, J. (2004a). Trust the Text: Language, Corpus and Discourse. London/New York: Routledge.

Sinclair, J. (2004b). Meaning in the Framework of Corpus Linguistics. Lexicographica, $20,20-32$.

Sorli, M. (2013). Forms of encoding pragmatic meaning: Semantic prosody. A lexicographic perspective. Lingue e Linguaggi, 10, 95-111.

Stewart, D. (2010). Semantic Prosody. A Critical Evaluation. London: Routledge.

Stubbs, M. (1995). Collocations and Semantic Profiles. Functions of Language, 2, 23-55.

Stubbs, M. (1996). Text and Corpus Linguistics. Oxford: Blackwell.

Stubbs, M. (2001a). Words and Phrases: Corpus Studies of Lexical Semantics. Oxford: Blackwell Publishing.

Stubbs, M. (2001b). On inference theories and code theories: corpus evidence for semantic schemas. Text, 21, 436-465.

Taylor, C. (2009). The representation of immigrants in the Italian press. CIRCaP Occasional Papers, 21, 1-40.

The Migration Observatory at the University of Oxford (2013). Report on Migration on the News: Portrayals of Immigrants, Migrants, Asylum Seekers and Refugees in National British Newspapers, 2010-2012 [on-line]. Retrieved from: http://www.migrationobservatory.ox.ac.uk/sites/files/migobs/Report $\% 20$ $\% 20$ migration $\% 20 \mathrm{in} \% 20$ the $\% 20$ news.pdf

Tognini-Bonelli, E. (2001). Corpus Linguistics at Work. Studies in Corpus Linguistics. Amsterdam: John Benjamins.

Tribble, C. (2000). Genres, Keywords, Teaching: Towards a Pedagogic Account of the Language of Project Proposals. In L. Burnard \& T. McEnery (Eds.), Rethinking Language Pedagogy from Corpus Perspective (pp. 74-90). New York: Peter Lang.

Whichmann, A., Simon-Vandenberger, A. M. \& Aijmer, K. (2010). How prosody reflect semantic change: a synchronic case study of 'of course'. In K. Davidse (Ed.), Subjectification, Intersubjectification and grammaticalization (pp. 103-154). Berlin: De Gruyter Mouton.

Whitsitt, S. (2005). A critique of the concept of semantic prosody. International Journal of Corpus Linguistics, 10, 283-305.

Widdowson, H. (2000). On the limitations of linguistics applied. Applied Linguistics, 21, 3-25. 
Xiao, R. \& McEnery, T. (2006). Collocation, Semantic Prosody, and Near Synonymy: A Cross-Linguistic Perspective. Applied Linguistics, 27, 103-129.

Zhang, R. (2013). A corpus-based study of semantic prosody change: The case of the adverbial intensifier. Concentric: Studies in Linguistics, 39(2), 61-82.

NOTE

1 (a) Provenance/transit/destination, (b) number, (c) entry, (d) economic problems, (e) residence, (f) return/repatriation, $(\mathrm{g})$ legality and $(\mathrm{h})$ plight. 